\title{
Isolation of sox9 duplicates in catfish: localization, differential expression pattern during gonadal development and recrudescence, and hCG-induced up-regulation of sox 9 in testicular slices
}

\author{
Kavarthapu Raghuveer and Balasubramanian Senthilkumaran \\ Department of Animal Sciences, School of Life Sciences-Centre for Advanced Studies, University of Hyderabad, \\ PO Central University, Hyderabad 500 046, Andhra Pradesh, India
}

Correspondence should be addressed to B Senthilkumaran; Email: bsksl@uohyd.ernet.in

\begin{abstract}
In vertebrates, $\operatorname{sox} 9$ is a transcription factor that plays a crucial role in testicular development and chondrogenesis. Here, we report cloning of isoforms of $\operatorname{sox} 9$ ( $\operatorname{sox} 9 \mathrm{a}$ and $\operatorname{sox} 9 \mathrm{~b}$ ) from air-breathing catfish Clarias gariepinus, which undergoes an annual reproductive cycle. Tissue distribution pattern showed differential expression of sox 9 duplicates, wherein both forms were highly expressed in brain and gonads. Furthermore, we observed a dimorphic expression pattern of sox9a and sox $9 b$ in both adult and developing gonads using RT-PCR, indicating that sox9a retained its function in testis while sox $9 b$ might have a new role to play in ovary. Changes in sox 9 mRNA levels using real-time quantitative PCR (qRT-PCR) during the seasonal reproductive cycle revealed that sox9a transcript in testis was abundant during testicular recrudescence (during spermatogenesis), and its expression significantly decreased during spawning and postspawning phases. Furthermore, treatments of human chorionic gonadotropin and 11-ketotestosterone in vitro up-regulated sox9a mRNA levels in the testicular slices at 12 and $24 \mathrm{~h}$ time points, suggesting that gonadotropins might stimulate sox 9 expression. These results suggest that sox 9 might have a plausible role in the entrainment of the testicular cycle. In contrast, during the ovarian cycle, sox $9 b$ mRNA levels gradually declined from preparatory to post-spawning phases. Immunohistochemical (IHC) data showed that, in testis, sox 9 is detectable in Sertoli and spermatogonial cell types except spermatid/spermatozoa. In the ovary, it is localized in the ooplasm of primary and pre-vitellogenic oocytes. These results were further confirmed by whole-mount IHC and qRT-PCR.

Reproduction (2010) 140 477-487
\end{abstract}

\section{Introduction}

The SOX (SRY-related high mobility group (HMG) box) gene family encodes several transcription factors that possess a DNA-binding motif known as the HMG domain (Sinclair et al. 1990). The HMG domain of all SOX proteins contains 79 amino acid residues, which is highly conserved across different phyla. SOX9 was first identified as the gene responsible for autosomal $X Y$ sex reversal associated with campomelic dysplasia, a human skeletal malformation syndrome (Foster et al. 1994, Wagner et al. 1994). Sox9 is the direct target of the testicular sex-determining gene, Sry (Sekido \& LovellBadge 2008). Sox9 transcription is up-regulated in the presence of Sry in developing pre-Sertoli cells during male development (Kent et al. 1996, Sekido et al. 2004). However, Sox9 overexpression in the genital ridges resulted in normal male development in transgenic mice lacking Sry (Bishop et al. 2000, Qin \& Bishop 2005). In mammals, birds, and turtles, expression of sox 9 is up-regulated in the developing male genital ridges during testicular differentiation (Kent et al. 1996, Morais da Silva et al. 1996, Moreno-Mendoza et al. 1999). In mice, ectopic expression of Sox9 in XX gonads resulted in the formation of testis (Vidal et al. 2001). These results together suggest for a crucial role of sox 9 in testicular development of several vertebrates. In addition to this, sox9 is also involved in the regulation of many developmental events such as notochord maintenance (Barrionuevo et al. 2006), prostate development (Thomsen et al. 2008), and cartilage formation in vertebrate species, including teleosts (Bi et al. 1999, Chiang et al. 2001, Yan et al. 2002).

To date, the sox 9 gene has been identified in several vertebrate species including mammals (Foster et al. 1994, Wagner et al. 1994, Kent et al. 1996), birds (Morais da Silva et al. 1996), reptiles (Moreno-Mendoza et al. 1999, Western et al. 1999, Choudhary et al. 2000), amphibians (Takase et al. 2000), and fishes (Takamatsu et al. 1997, Chiang et al. 2001, Yokoi et al. 2002). Two different forms of sox9 genes have been identified in 
teleosts like zebrafish, rice field eel, fugu, and medaka (Chiang et al. 2001, Zhou et al. 2003, Koopman et al. 2004, Klüver et al. 2005). These two forms of sox9 gene were found to be orthologs of the tetrapod Sox9 gene that arose during a whole-genome duplication event (Amores et al. 1998, Postlethwait et al. 2004). In rainbow trout, sox9 was expressed in testis (Takamatsu et al. 1997), while in medaka, sox9 was expressed in ovary (Yokoi et al. 2002). In zebrafish, sox9a was expressed in testis, as in mammals, and sox9b in ovary (Chiang et al. 2001). In rice field eel, two sox9a genes (sox9a1 and sox9a2) were expressed in testis, ovary, and ova-testis (Zhou et al. 2003). In medaka, sox9a2 was isolated, and found to be expressed at the highest level in adult testis (Nakamoto et al. 2005). In common carp, sox9b was expressed in testis (Du et al. 2007). These results suggest that the expression of sox9 in gonads seems to be somewhat diversified in teleosts. Most of these studies were done during early gonadal development in daily or fortnight breeders like zebrafish, medaka, and tilapia. In this regard, catfish (Clarias gariepinus) is an annual breeder, which undergoes seasonal pattern of gonadal attenuation and recrudescence that may provide interesting highlights to understand the role of sox9 not only during development but also during recrudescence. In the present study, we cloned full-length cDNAs of sox9a and sox $9 b$ from catfish gonads, and analyzed their expression pattern in different stages of gonadal development and recrudescence. Extensive analysis was also made to localize Sox9 protein for the first time in developing and adult gonads. We also studied the expression pattern of sox9 in human chorionic gonadotropin (hCG) and 11-ketotestosterone (11-KT) -treated testicular slices at different time intervals by an in vitro culture.

\section{Results \\ Cloning of sox9a and sox9b from catfish gonads}

Two distinct partial cDNA fragments of sox 9 were identified in catfish: sox9a (269 bp) from testis and sox9b (266 bp) from ovary using RT-PCR with degenerate primers. The $5^{\prime}$ and $3^{\prime}$ ends of these partial cDNA fragments were amplified using RACE PCR. The fulllength catfish sox9a cDNA isolated (2065 bp) from testis had an open reading frame (ORF) of 1383 bp encoding a putative protein of 460 amino acid residues. Catfish sox9b cDNA (2059 bp) obtained from ovary had an ORF of $1377 \mathrm{bp}$ encoding a putative protein of 458 amino acid residues. ClustalW alignment of these two duplicates, sox9a and sox9b from catfish, showed $62 \%$ homology between them at the amino acid level (Fig. 1). Multiple sequence alignment reveals that the HMG box domain is highly conserved, with more than $96 \%$ sequence identity with other vertebrates. Sequence homology among sox 9 from different species other than the HMG domain showed an overall $70-85 \%$ sequence identity among all other known vertebrate SOX9 proteins. Phylogenetic analysis using neighbor-joining method revealed that the catfish sox9a was closely

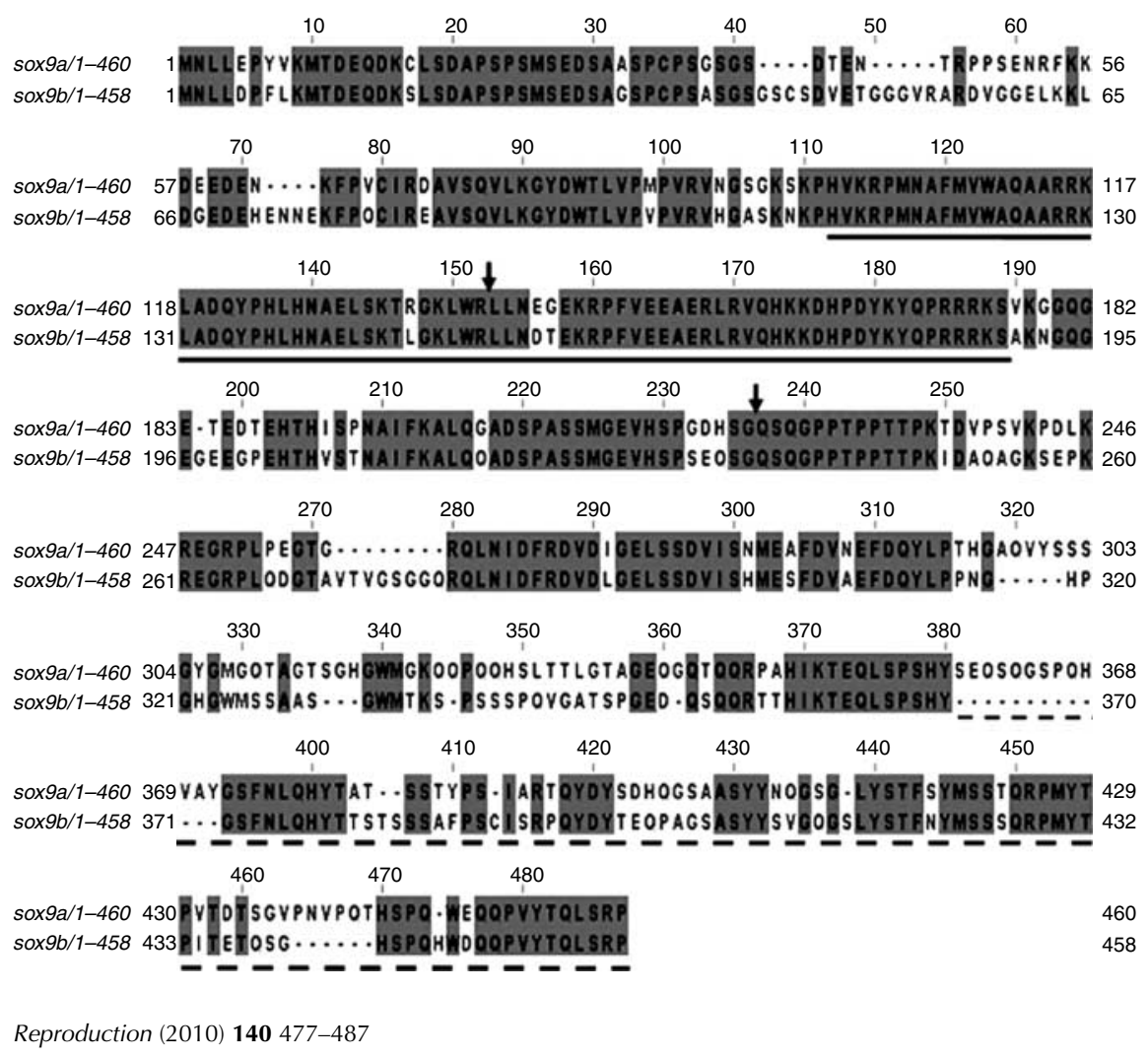

Figure 1 ClustalW alignment of deduced amino acid sequences of catfish sox 9 a and sox $9 \mathrm{~b}$. This alignment was created using the ClustalW alignment software version 1.82 from European Bioinformatics Institute website (http://www.ebi.ac.uk/ Tools/clustalw2). Arrows indicate intron positions. Solid lines indicate conserved HMG box region, and dotted lines indicate transactivation domain. 
related to rainbow trout, while catfish sox $9 b$ was clustered with sox $9 b$ of carp and zebrafish (Fig. 2). The nucleotide sequence data of sox9a and sox9b have been submitted to GenBank. The accession number of catfish sox9a is HM149258 and sox9b is HM149259.

\section{Tissue distribution pattern of sox9 duplicates by RT-PCR}

Tissue distribution analysis by RT-PCR showed that the expression of sox9a (Fig. 3A) was confined to few tissues like brain, heart, gill, liver, kidney, and testis. On the other hand, sox9b transcript (Fig. 3A) was detectable in brain, heart, liver, ovary, and spleen. However, in both cases, sox 9 was abundantly expressed in brain and gonads. Interestingly, sox9a and sox9b depicted sexual dimorphism.

\section{Dimorphic expression pattern of sox9a and sox9b in adult and developing gonads}

Further analysis of sexual dimorphism of sox9 by semiquantitative RT-PCR endorsed that sox9a was detectable in adult testis while sox $9 b$ was expressed in adult ovary (Fig. 3B). This kind of expression pattern of sox9 duplicates was observed in developing gonads at different age groups $(50,75,100$, and 150 days post

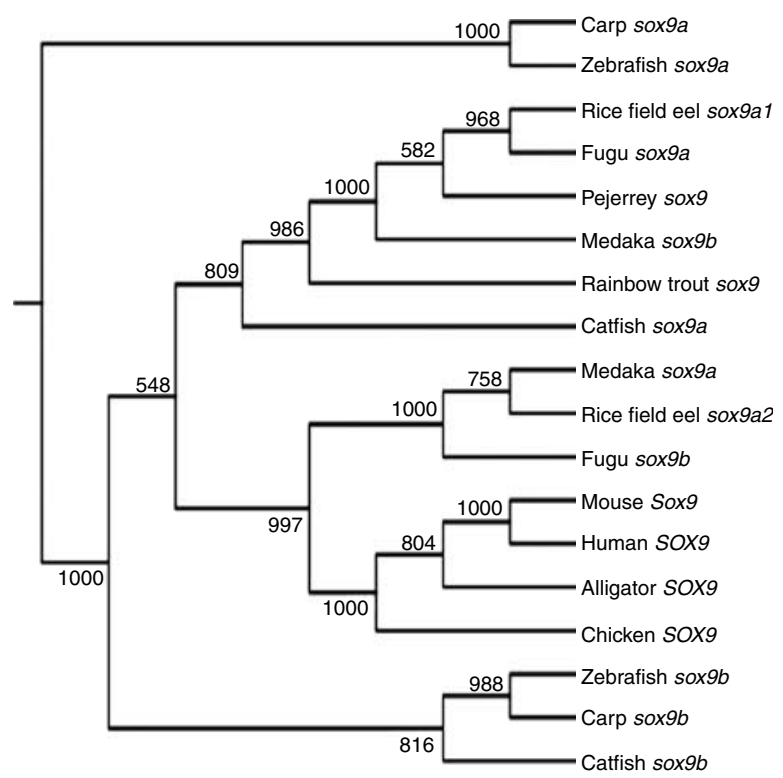

Figure 2 Phylogenetic tree showing the evolutionary status of catfish sox9a and sox9b. The tree was constructed using the neighbor-joining method, and a bootstrap analysis with 1000 replicates was used to assess the strength of nodes in the tree. Phylogenetic analysis was done using CLC Main workbench 5 software. GenBank accession numbers are as follows: human (CAA86598), mouse (NP_035578), chicken (AAB09663), alligator (AAD17974), rainbow trout (BAA24365), pejerrey (AAP84605), zebrafish sox9a (AF277096), carp sox9a (AAZ07990), fugu sox9a (AAQ18507), medaka sox9a (AAX62152), rice field eel sox9a1 (AAK59254), zebrafish sox9b (AF277097), carp sox9b (AAX56088), fugu sox9b (AAQ18508), medaka sox9b (AAX62151), and rice field eel sox9a2 (AAK59255).

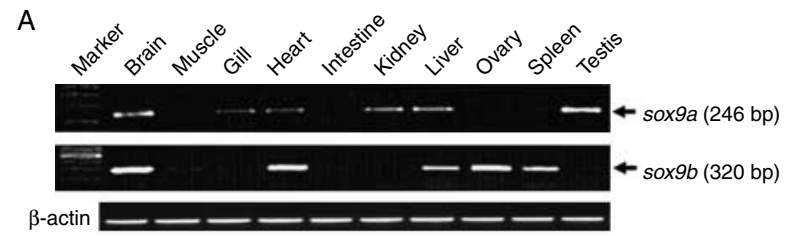

B

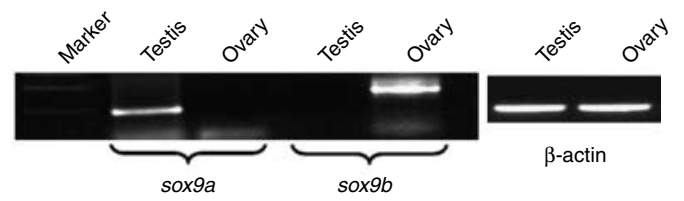

C

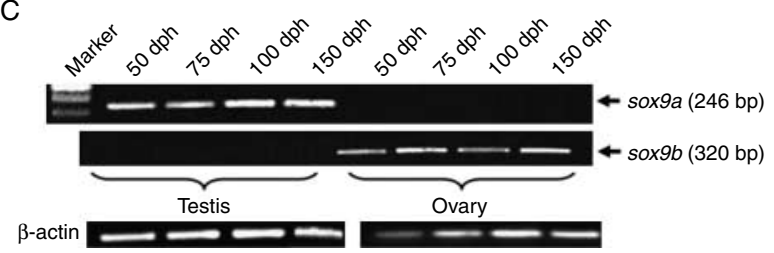

Figure 3 (A) RT-PCR analysis of sox $9 a$ and sox $9 b$ in different tissues of adult catfish. (B) Semi-quantitative RT-PCR analysis $(n=3)$ of sox 9 duplicates in adult testis and ovary. (C) Semi-quantitative RT-PCR $(n=3)$ amplification of sox $9 a$ and sox $9 b$ in developing gonads at different age groups of catfish (50, 75, 100, and 150 days post hatching). $\beta$-actin was used as an internal endogenous control.

hatching (dph)) in catfish, wherein sox9a expression was seen in developing testis but not in developing ovary, and the reverse is true for sox $9 b$ (Fig. 3C).

\section{Expression of sox9 in different phases of testicular and ovarian cycles}

Real-time quantitative PCR (qRT-PCR) analysis revealed that sox9a expression was significantly higher during preparatory and pre-spawning phases when compared with spawning and post-spawning phases of testicular cycle (Fig. 4A). This indicates that sox9a transcripts are abundantly expressed during active spermatogenesis, i.e. in preparatory and pre-spawning phases, wherein spermatogonia and spermatocytes (SC) are more in number (Swapna et al. 2006), while sox9b transcript was abundantly expressed during preparatory phase, and later its expression was drastically reduced in prespawning, spawning, and post-spawning phases of the ovarian cycle (Fig. 4B).

\section{Effect of hCG treatment in vitro on sox9a expression in the testicular slices}

To test whether sox9a expression can be regulated by gonadotropins, hCG treatment was done, as it is functionally similar to $\mathrm{LH}$. Expression of sox9a was analyzed in testicular slices (late preparatory phase of mature fish) that were collected at different time intervals after the treatment of hCG in vitro using qRT-PCR. 

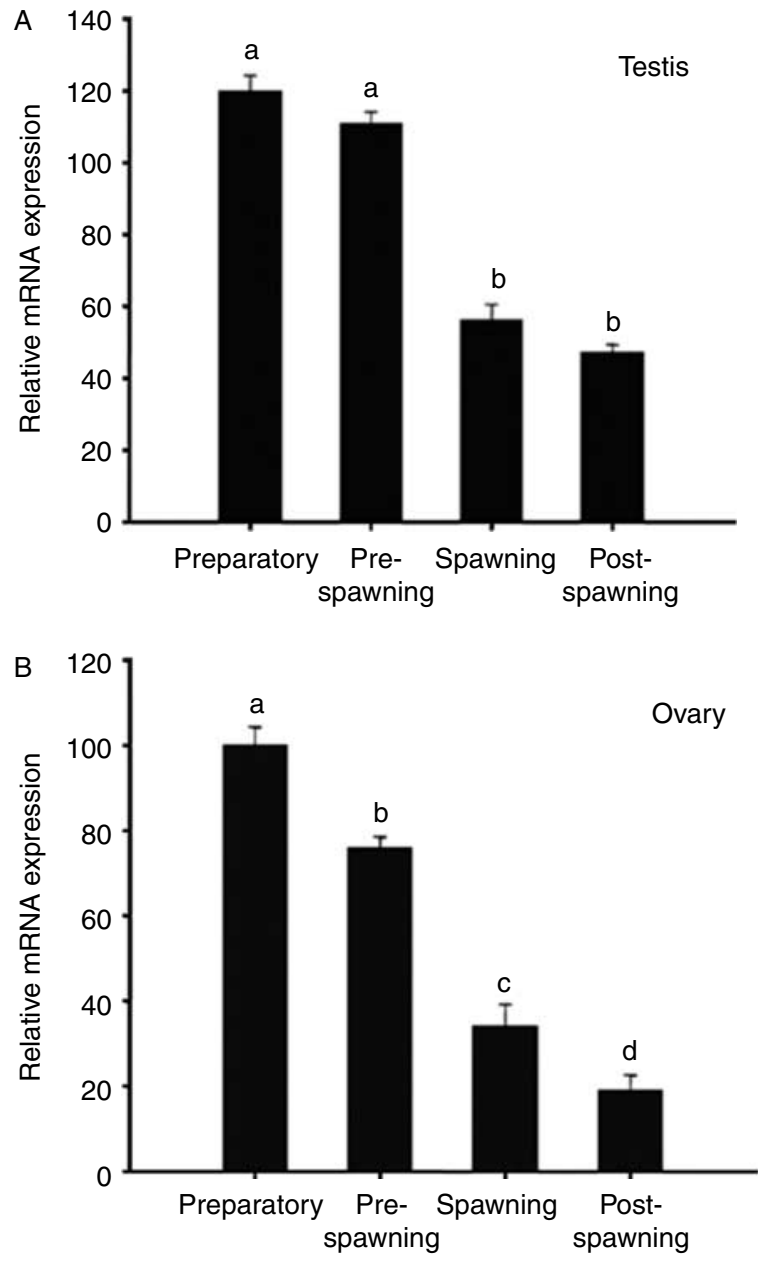

Figure 4 (A) qRT-PCR analysis of sox9a expression during different phases of the testicular cycle in catfish. The relative expression of sox9a normalized with $\beta$-actin in samples was calculated using comparative $C_{\mathrm{t}}$ method. Data for real-time PCR were expressed as mean \pm S.E.M. $(n=5)$. Different letters on the bars indicate significant increase in the mRNA levels in preparatory and pre-spawning phases from that of spawning and post-spawning phases $(P<0.05$, ANOVA followed by SNK test). Same letters on the bars indicate that the differences were not significant. (B) qRT-PCR analysis of sox $9 b$ expression during different phases of the ovarian cycle in catfish. Other details are as in Fig. 4A.

The expression of sox9a was significantly increased at $12 \mathrm{~h}(* P<0.05)$ and peaked at $24 \mathrm{~h}\left({ }^{* *} P<0.001\right)$ after hCG treatment (Fig. 5).

\section{Effect of 11-KT treatment in vitro on sox9a expression in the testicular slices}

Since hCG is known to induce androgen production in testis, we intend to study the effect of 11-KT (a potent androgen in fish) on sox9a expression in testicular slices. The qRT-PCR analysis revealed that the 11-KT treatment has significantly increased the sox9a transcripts in testicular slices (late preparatory phase of mature fish) at $12 \mathrm{~h}\left({ }^{*} P<0.05\right)$ and $24 \mathrm{~h}(* * P<0.001)$ time points when compared with $0 \mathrm{~h}$ (Fig. 6).

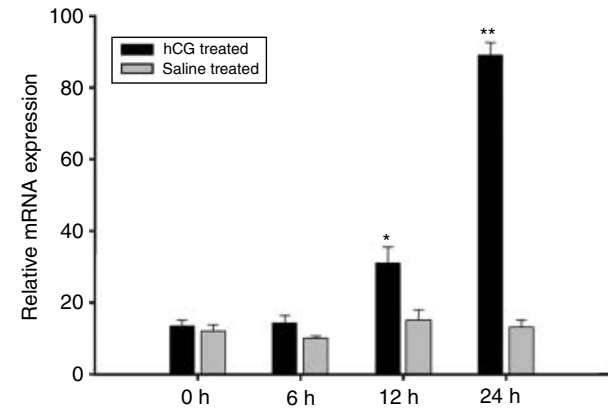

Figure 5 qRT-PCR analysis showing sox9a mRNA levels in the testicular slices treatment with hCG in vitro at different time intervals. sox9a mRNA levels were significantly increased after hCG induction in vitro at 12 and $24 \mathrm{~h}$ time points compared with the $0 \mathrm{~h}$ time point. ${ }^{*} P<0.05$; ${ }^{* *} P<0.001$ (ANOVA followed by SNK test, $n=3$ ).

\section{Expression pattern of sox9b in different stages of follicles}

We collected four different stages of follicles (Fig. 7A) from catfish ovary during pre-spawning period: stage I (perinucleolar/primary oocytes), stage II (pre-vitellogenic oocytes), stage III (vitellogenic oocytes), and stage IV (post-vitellogenic oocytes). qRT-PCR was performed to quantify the sox $9 b$ transcript abundance in these four stages of oocytes. The real-time PCR results (Fig. 7B) showed that the transcript was abundantly expressed in stage I oocytes, moderately low in stage II oocytes $\left({ }^{*} P<0.05\right)$, and its expression was drastically reduced in stage III and IV oocytes $(* * P<0.001)$.

\section{Localization of Sox9 in developing and adult gonads of catfish}

Western blot analysis revealed an expected band of $\sim 51 \mathrm{kDa}$ in testis and ovarian tissue homogenates of catfish. This band corresponds to the Sox9 protein, which encodes a $51 \mathrm{kDa}$ putative protein (Fig. 8). Absence of immunoreactivity using the antibody preabsorbed with Sox9 synthetic peptide confirms that the primary antibody is indeed specific to Sox9 protein

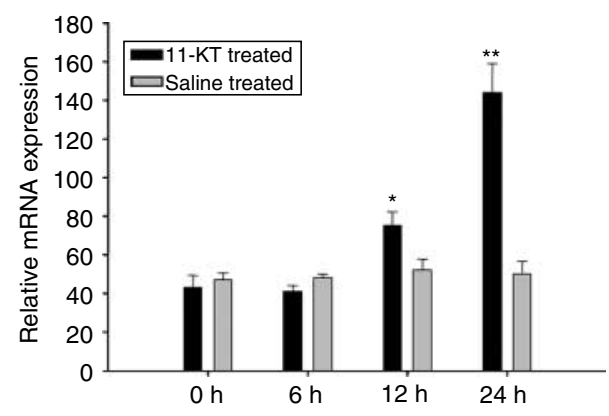

Figure 6 qRT-PCR analysis showing sox9a mRNA levels in the testicular slices treatment with $11-\mathrm{KT}(100 \mathrm{ng} / \mathrm{ml})$ in vitro at different time intervals. sox9a mRNA levels were significantly increased after hCG induction in vitro at 12 and $24 \mathrm{~h}$ time points compared with the $0 \mathrm{~h}$ time point. ${ }^{*} P<0.05$; ${ }^{* *} P<0.001$ (ANOVA followed by SNK test, $n=3$ ). 


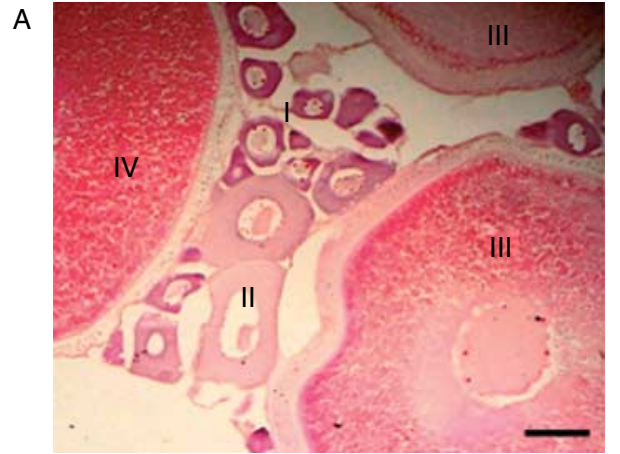

I. Perinucleolar oocyte

II. Pre-vitellogenic oocyte

III. Vitellogenic oocyte

IV. Post-vitellogenic oocyte

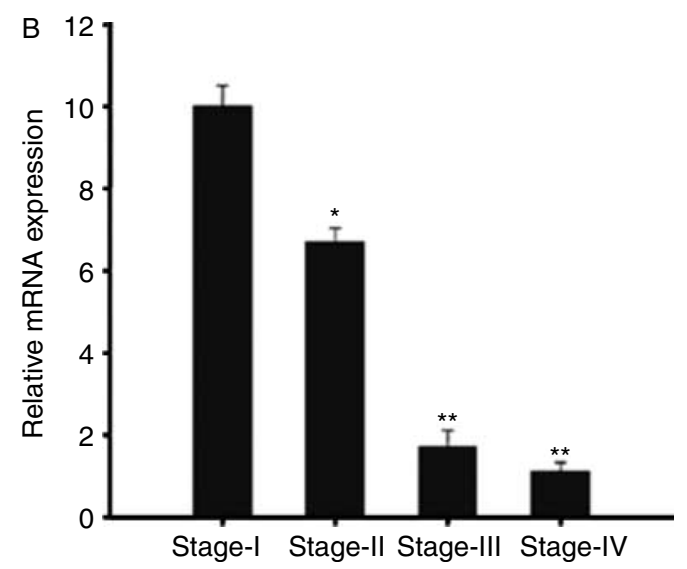

Figure 7 (A) Hematoxylin-eosin-stained section of mature catfish ovary showing different stages of oocytes. Scale bar indicates $50 \mu \mathrm{M}$. (B) qRT-PCR analysis showing the expression pattern of sox $9 b$ in different stages of oocytes. The relative expression of sox $9 b$ in different stages was calculated using comparative $C_{\mathrm{t}}$ method. sox $9 \mathrm{~b}$ mRNA levels were significantly lower in stage II, III, and IV oocytes, when compared with stage I oocytes. ${ }^{*} P<0.05$; ${ }^{*} P<0.001$ (ANOVA followed by SNK test, $n=5$ ).

in catfish (Fig. 9A). Immunohistochemical (IHC) analysis in the preparatory phase of adult testis revealed that Sox9 immunoreactivity was observed in Sertoli and spermatogonial cell types such as primary spermatogonia (SG1), secondary spermatogonia (SG2), and SC except spermatid/spermatozoa (SP; Fig. 9B-D). In the case of adult ovary, Sox9 immunoreactivity was restricted to ooplasm of stage I and stage II oocytes (Fig. 9E). This was further confirmed by the whole-mount IHC in different follicular stages (oocytes), wherein the signal was abundant in stage I and stage II oocytes (Fig. 9F and G). No signal was detectable in stage III and stage IV oocytes (Fig. 9G). No immunoreactivity was observed with pre-absorbed antibody (negative control, Fig. 9H). During the critical period of gonadal differentiation in catfish, Sox9 protein was detectable in germ and supporting cells of undifferentiated gonad at $40 \mathrm{dph}$ (Fig. 8I). Sox9 immunoreactivity was prominent in the primary oocytes (stage I) and oogonia of differentiated ovary at $50 \mathrm{dph}$ and in stage I and II oocytes of juvenile ovary at $100 \mathrm{dph}$ (Fig. 9J and K), whereas in developing testis at $100 \mathrm{dph}$, it was observed in the Sertoli and germ cells present in cysts (Fig. 9L)

\section{Discussion}

In the present study, we report cloning of two duplicate orthologs of sox9, named sox9a and sox9b. Both the isoforms contain the Sox gene signature domain HMG, which is highly conserved across different vertebrates. Recent studies in teleosts like zebrafish, medaka, rice field eel, and carp also reported two forms of sox 9 (Chiang et al. 2001, Zhou et al. 2003, Klüver et al. 2005, Du et al. 2007). Phylogenetic analysis using neighbor-joining method revealed that the isolated catfish sox9 duplicates showed high homology to its counterpart in yellow catfish and zebrafish. Previously, Klüver et al. (2005) reported in medaka that the two sox9 genes are co-orthologs of the single tetrapod Sox9. This was reliable with whole-genome duplication in the ray-fin lineage (Amores et al. 1998, Postlethwait et al. 2004) that might have promoted lineage divergence by partitioning different ancestral gene subfunctions among co-orthologs of tetrapod genes (Lynch \& Force 2000, Cresko et al. 2003). Zhou et al. (2003) also reported that the sox9 gene was duplicated during the evolution of rice field eel. The duplicated copies of the sox 9 gene showed similar kind of expression pattern in testis, ovary, and ova-testis. Tissue distribution analysis in catfish showed differential expression pattern of sox9a and sox $9 \mathrm{~b}$. In catfish, both the isoforms are expressed abundantly in brain and gonads. Semi-quantitative RT-PCR analysis in adult gonads revealed sexual dimorphic expression of sox9a and sox9b in adult and

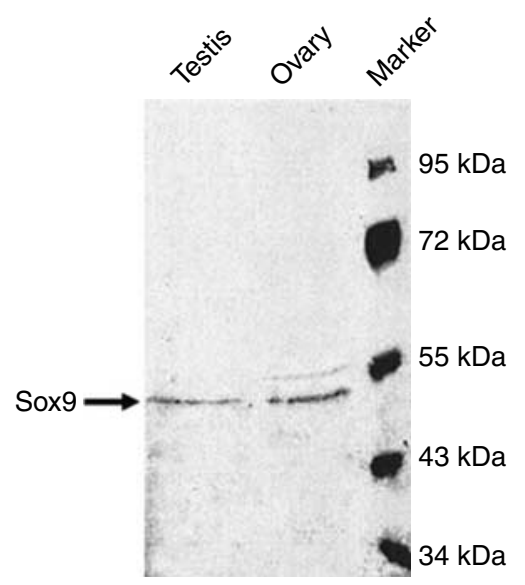

Figure 8 Western blot showing Sox9 protein (band) of molecular weight $\sim 51 \mathrm{kDa}$ detectable in testis and ovary of adult catfish, which is consistent with the size, calculated using the LaserGene software (51224.06 Da) from the deduced amino acid sequence of Sox9. Arrow indicates Sox9 protein (band). 

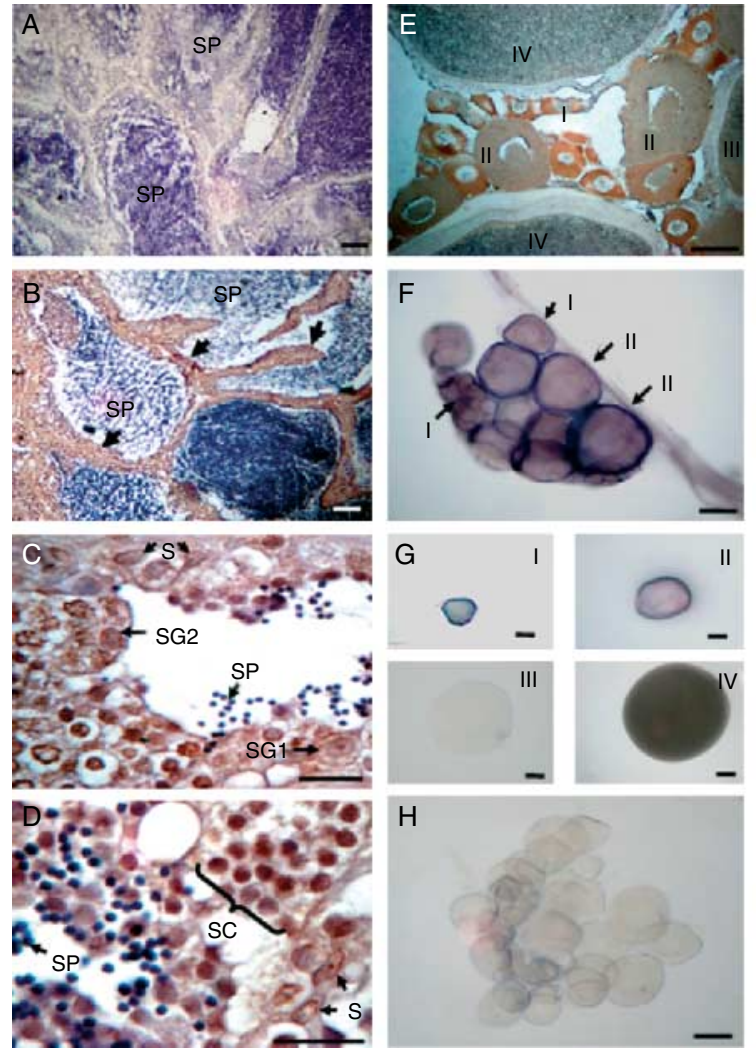
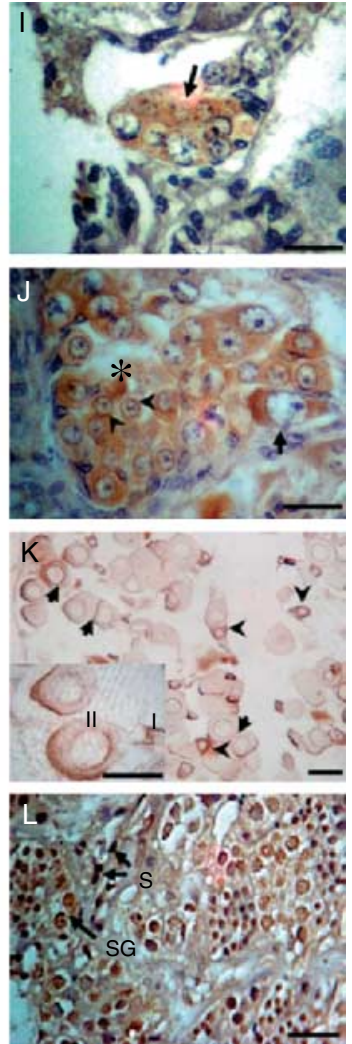

Figure 9 Immunocytochemical (IHC) localization of Sox9 protein in adult testis using anti-human Sox9 antibody. (A) Negative control showing Sox9 immunoreactivity was abolished when pre-absorbed antibody was used as the primary antibody. (B) Adult testis section showing Sox9 immunoreactivity in boundaries of lumens filled with spermatids/sperm (SP); arrowheads indicate positive immunoreactivity. (C and D) Adult testis section at higher magnification showing Sox9 signal was detectable in Sertoli and spermatogonial cell types except spermatid/sperm (SP). Arrows indicate the position of the cell types: Sertoli cells (S), primary spermatogonia (SG1), secondary spermatogonia (SG2), spermatocytes (SC), and SP. Counterstained with hematoxylin. (E) IHC detection of Sox9 in different oocytes of mature female. Sox9 protein was detectable only in stage I (primary oocytes) and stage II (pre-vitellogenic oocytes) oocytes of mature ovary using IHC. There was no signal in stage III and stage IV oocytes. (F and G) Whole-mount IHC localization of Sox9 protein in different stages of oocytes. $(\mathrm{H})$ Negative control showing no signal when pre-absorbed Sox9 antibody was used as the primary antibody. (I) Sox9 signal in germ cells (shown by arrow) of undifferentiated gonad at $40 \mathrm{dph}$. (J) Differentiated ovary at $50 \mathrm{dph}$. Arrows indicate primary oocytes, arrowheads indicate oogonial cells, and * indicates ovarian cavity. (K) Developing ovary at $100 \mathrm{dph}$. Arrows indicate primary oocytes and arrowheads indicate pre-vitellogenic oocytes. Inset shows immunoreactivity in stage I and stage II oocytes at higher magnification. (L) Immature testis at $100 \mathrm{dph}$. Counterstained with hematoxylin. All scale bars indicate $50 \mu \mathrm{M}$.

developing gonads, wherein sox9a was preferably expressed in testis, while sox $9 b$ was abundantly expressed in ovary. This type of differential expression pattern of duplicated genes may attribute to more flexible gene regulation and function during catfish development. A similar kind of expression pattern was also noticed in zebrafish using PCR Southern and in situ hybridization (Chiang et al. 2001). Sexual dimorphic expression pattern of sox9a was observed 25 days after hatching in a monosex population of Nile tilapia (Kobayashi et al. 2008). This kind of dimorphic expression pattern of sox9 duplicates in fish gonads indicates that sox9a retained its function as a testisspecific gene, while sox9b might have a new role to play in ovarian development. Male-specific expression pattern of sox9a was also observed in fresh water and marine turtles suggesting its role in testicular differentiation (Spotila et al. 1998, Moreno-Mendoza et al.
1999). In contrast, there are a few reports wherein sox 9 duplicates did not show any dimorphic expression in the gonads of medaka and eel (Zhou et al. 2003, Klüver et al. 2005).

In mammals and birds, sox9 expression was downregulated during ovarian differentiation, but its expression was high in developing testis and remains throughout adulthood (Kent et al. 1996, Morais da Silva et al. 1996). As sox9 expression still persists after gonadal development, its role during adulthood in teleosts is yet to be defined. The fate of sox9 in different phases of adult gonads during the reproductive cycle has not been studied in detail so far in any teleosts. To this end, we quantified sox 9 transcript abundance in different stages of testicular and ovarian cycle. Real-time PCR analysis of sox9a during testicular cycle showed that the transcript was higher during the period of spermatogenesis, i.e. preparatory and pre-spawning phases, and its expression 
decreased gradually thereafter during spermiation and post-spawning phases. This high expression during spermatogenesis is due to a higher number of germ cells expressing sox9. In contrast, during the ovarian cycle, expression of sox9b transcript was abundant in the preparatory phase when compared with the prespawning phase, spawning, and post-spawning phases. Recent report showed that Gnrh analog treatment (in vitro and in vivo) up-regulates sox3 and dmrt1 mRNA expression in immature black porgy (Shin et al. 2009). In another study, it was observed that FSH could regulate Dmrt1 expression in postnatal rat testis (Chen \& Heckert 2001). In light of this finding, the role of gonadotropins, if any, on the regulation of sox 9 mRNA expression is not known in lower vertebrates. Hence, we studied the expression of sox 9 after hCG induction specifically during testicular recrudescence, as sox 9 expression tends to be at higher levels in preparatory and pre-spawning phases. We observed a significant increase in sox9a mRNA in the testicular slices (prepared from testis in late preparatory phase) upon treatment with hCG in vitro at 12 and $24 \mathrm{~h}$ time points. This result tends to propose a role for gonadotropins in sox 9 regulation, at least in testis. In this regard, LH-like hCG is known to bind to LH receptors, which is expressed by Leydig cells to stimulate androgen production and acts on Sertoli cells to influence spermatogenesis (Skinner 1991). In fish, it is well known that hCG (functionally similar to $\mathrm{LH}$ ) induces testosterone and 11-KT production in vitro (Wade \& Van der Kraak 1991). Hence, it is possible that hCG might have induced sox9a via androgen production. To test this contention, we also studied the effect of 11-KT on sox9a expression in testicular slices (in vitro culture). In this study, for the first time, we demonstrated that the treatment with 11-KT significantly elevated the expression of sox9a in testicular slices. This may be one of the modes of action for gonadotropins. The androgen receptor present in Sertoli cells is known to regulate specific genes such as Rhox $5 / P e m$, which is required for the gametogenesis in mice (Verhoeven et al. 2010). However, in this study, the specific mechanism of how androgens regulate sox9a expression in Sertoli cells needs to be elucidated. Furthermore, there are reports which clearly show that gonadotropins like FSH can directly act on Sertoli cells and regulate the expression of other genes by activating other transcription factors like cAMP response element-binding protein (CREB) and CAMP response element modulator (CREM; Sassone-Corsi 1995). It has been reported that FSH can regulate the expression of Dmrt1 in Sertoli cells via the CAMP-PKA pathway by activating CREB or CREM (Chen \& Heckert 2001). In humans, it has been shown that the SOX9 promoter is regulated by CREB (Piera-Velazquez et al. 2007). These results altogether suggest that gonadotropins can regulate sox9 expression in Sertoli cells either directly or indirectly.
IHC data in male gonad revealed that Sox9 was localized in Sertoli cells and different stages of germ cells, while spermatid/spermatozoa did not show any signal. A similar localization pattern to that of Sox9 in germ cells was noticed for Dmrt1 in catfish, zebrafish, red-spotted grouper, and mice (Guo et al. 2005, Xia et al. 2007, Raghuveer \& Senthilkumaran 2009) and for Sox3 in grouper (Xia et al. 2007), which are related to testicular development. This contention requires more validation. Nevertheless, we used a highly specific antibody that detects only Sox9 protein in Sertoli cells of human testis (as per antibody characterization data from the manufacturer). Hence, the observation of Sox9 protein in Sertoli and germ cells in catfish is acceptable technically, and we presume that the detection of Sox9 may be a feature observed in siluriformes like that of Dmrt1. However, in zebrafish, sox9 expression was confined only to Sertoli cells of testis (Chiang et al. 2001). The presence of Sox9 protein in oogonia during ovarian differentiation is shown for the first time in any lower vertebrates. This further validates that Sox9 protein is also detectable in germ cells. However, the difference in subcellular localization of male and female germ cells of the protein recognized by the anti-sox 9 antibody is quite striking, as it is found in the nucleus of male germ cells while there is little to no signal in the nucleus of developing oogonia. The apparent reason for low detection of this transcription factor (Sox9 protein) in the nucleus of female germ cell is not clear at the moment. In accordance with our findings, sox 9 transcripts were shown to be detectable mostly in the cytosol of immature oocytes of zebrafish by in situ hybridization (Chiang et al. 2001). In mature female catfish, sox9 expression was restricted to perinucleolar stage of developing oocytes and pre-vitellogenic oocytes, but not in mature oocytes. In the whole-mount IHC, Sox9 signal was more in the periphery with less intensity in ooplasm. On the other hand, in the cross section of mature ovary, the immunoreactivity was more clearly evident in ooplasm. The decrease in sox 9 transcript in mature oocytes may be due to the dilution of transcripts with increasing mass/size of mature oocytes that moreover accumulate large amount of vitellogenin and maternal RNAs. These results together indicate that sox9 may have an important role in early gonadal development and recrudescence.

In conclusion, we identified/isolated sox9 duplicates (sox9a and sox9b) in catfish gonads. Dimorphic expression pattern of sox 9 duplicates in developing gonads authenticates an important role for the correlates in gonadal development. Sox9 protein could be localized in Sertoli and germ cells of catfish testis. Its expression was prominent in immature oocytes, while it is negligible in mature oocytes. High expression of sox 9 during gonadal recrudescence indicates its importance in the entraining of the gonadal cycle in teleosts, which may be regulated by gonadotropins. 


\section{Materials and Methods}

\section{Animals and sampling}

Catfish (Clarias gariepinus) at different age groups were reared in fresh water tanks under ambient photothermal conditions. Mature spermiating male and gravid female fishes injected with hCG were used for IVF to obtain catfish fries at different age groups. The newly hatched catfish fries were fed with live tubeworms until 3 months. Juvenile fishes of 3-8 months old were fed with live tubeworms besides commercially available fish feed pellets. Adult catfish ( 1 year old) were reared in the outdoor tanks of the laboratory and fed with minced goat liver ad libitum in addition to fish feed. Commonly referred to as the African or air-breathing catfish, this species is abundantly available in ponds and lakes of Hyderabad. The seasonal reproductive cycle of catfish is divided into four phases as follows (Swapna et al. 2006): preparatory (February-April), prespawning (May-June), spawning (July-October), and postspawning/regressed phases (November-January). The seasonal reproductive cycle is seen both in wild caught and in natural outdoor tank-maintained fishes. Adult gonads of catfish were collected during reproductive cycle and a part of it was fixed in $4 \%$ paraformaldehyde (PFA), while remaining tissue was stored at $-80{ }^{\circ} \mathrm{C}$ for total RNA extraction. As reported earlier, the morphological signs of sex differentiation were completed at $50 \mathrm{dph}$ in catfish (Raghuveer \& Senthilkumaran 2009). Juvenile catfish fries at different age groups (50, 75, 100, and $150 \mathrm{dph}$ ) were dissected, and gonads were removed using a fine forceps under stereozoom microscope. Gonads (five to ten fishes) of similar age group and same sex were pooled and stored at $-80{ }^{\circ} \mathrm{C}$ for total RNA extraction. Oocytes at different maturation stages were collected from pre-spawning female catfish. Oocytes were separated under stereozoom microscope in F.O. solution $\left(113 \mathrm{mM} \mathrm{NaCl}, 1 \mathrm{mM} \mathrm{KCl}, 2 \mathrm{mM} \mathrm{CaCl}_{2}, 5 \mathrm{mM}\right.$ HEPES, pH 7.5) in four different stages: stage I, perinucleolar/ primary oocytes $(<50 \mu \mathrm{m})$; stage II, pre-vitellogenic oocytes (50-100 $\mu \mathrm{m})$; stage III, vitellogenic oocytes (150-300 $\mu \mathrm{m})$; and stage IV, post-vitellogenic oocytes $(300-800 \mu \mathrm{m})$. After separation, total RNA was immediately prepared, without any freezing step.

\section{Cloning of partial cDNA fragments of sox9a and sox9b from catfish gonads}

Total RNA was prepared from adult catfish testis and ovary using the Sigma TRI-reagent method. RT was carried out using superscript-III (Invitrogen) with oligo $\mathrm{d}(\mathrm{T})_{18}$ primers and $5 \mu \mathrm{g}$ of total RNA at $50{ }^{\circ} \mathrm{C}$ according to the manufacturer's protocol. PCR amplification was done using a PCR master mix (Fermentas, Glen Burnie, MD, USA) under the following conditions: $94{ }^{\circ} \mathrm{C}(1 \mathrm{~min}), 55^{\circ} \mathrm{C}(1 \mathrm{~min})$, and $72{ }^{\circ} \mathrm{C}(1 \mathrm{~min})$ for 35 cycles using the sox $9 d g F r$ and sox $9 d g R v$ degenerate primers (Table 1) designed based on the available sox9 nucleotide sequences of other species from NCBI GenBank database. PCR-amplified cDNA fragments were gel purified, cloned in TOPO cloning vector (Invitrogen), and sequenced. The partial cDNA fragments of sox9a and sox9b obtained from testis and ovary respectively were confirmed using NCBI BLAST search.
Table 1 List of primers used for PCR amplification.

\begin{tabular}{|c|c|}
\hline Primers & Nucleotide sequence $\left(5^{\prime}-3^{\prime}\right)$ \\
\hline sox9dgFr & $\mathrm{GC}(\mathrm{AC}) \mathrm{GA}(\mathrm{GA})(\mathrm{CT}) \mathrm{T}(\mathrm{GC}) \mathrm{AGCAAAAC}(\mathrm{ATC}) \mathrm{C}(\mathrm{TG}) \mathrm{G}$ \\
\hline $\operatorname{sox} 9 \mathrm{dgRv}$ & CTGGA(TA)GC(TG)GG(CGA)A(AG)TCGG \\
\hline sox $9 a 5^{\prime} G S P 1$ & ACAAATGGCCGCTTCTCСССТTC \\
\hline sox $9 b 5^{\prime} G S P 1$ & TGCGTGTGCTCGGGACССТCTTCC \\
\hline sox9a5'GSP2 & AGCCGCCAGAGTTTGCCCCG \\
\hline sox $9 b 5^{\prime} G S P 2$ & TCCTTCGCCGTGGCTGGTACT \\
\hline sox9a3'GSP1 & AAGGGCGGCCAGGGTGAAACCG \\
\hline sox $9 b 3^{\prime} G S P 1$ & GCATCAGCCGGCCTCAGTACG \\
\hline sox9a3'GSP2 & AGCCСТACAGGGAGCCGACTC \\
\hline sox $9 b 3^{\prime} G S P 2$ & GAGTTCTAGCCAGAGGCCCATG \\
\hline sox9aF & ACCCAGAGGCCCATGTACAC \\
\hline $\operatorname{SOX} 9 \mathrm{a} R$ & CTGGTGGAGGGAGTGGAC \\
\hline SOX9bF & CGCAGTTACCGTTGGCTCTG \\
\hline $\operatorname{sox} 9 b R$ & GCTGCAGGTTGAAGGAGCCA \\
\hline$\beta$-actinRTF & GCAGAGCTCAGCAAAACCCGG \\
\hline$\beta$-actinRTR & GCTGGAAGCGGGAGAGTCGG \\
\hline Sox9aRTF & TCTGGCGGCTGCTGAATGAAGG \\
\hline SOX9aRTR & CTCGGTATCCTCGGTTTCACC \\
\hline SOX $9 b R T F$ & GAGACCCAGTCAGGCCACAG \\
\hline SOX9bRTR & AGGGTCTCGATGTGGGCCA \\
\hline
\end{tabular}

\section{RACE}

Full-length cDNAs of sox9a and sox9b were obtained from testis and ovary respectively using $5^{\prime}$ and $3^{\prime}$ RACE strategies. Gene-specific primers (GSP) for RACE were designed based on the sequence information of partial cDNA fragments of sox9a and sox9b (Table 1). SMART RACE cDNA amplification kit (Clontech) was used to prepare $5^{\prime}$ and $3^{\prime}$ cDNA templates from testis and ovary total RNA according to the manufacturer's protocol. To obtain $5^{\prime}$ and $3^{\prime}$ ends of sox 9 duplicates, we performed touchdown PCR using sox $9 a$ and sox $9 b 5^{\prime}$ and $3^{\prime}$ GSP1 primers (Table 1), and universal primer A mix with the RACE templates under following cycling conditions: $94{ }^{\circ} \mathrm{C}(30 \mathrm{~s})$ and $72{ }^{\circ} \mathrm{C}(2 \mathrm{~min})$ for 5 cycles, $94{ }^{\circ} \mathrm{C}(30 \mathrm{~s})$ and $70{ }^{\circ} \mathrm{C}(2 \mathrm{~min})$ for 5 cycles, $94^{\circ} \mathrm{C}(30 \mathrm{~s})$, and $68^{\circ} \mathrm{C}(30 \mathrm{~s})$ and $72{ }^{\circ} \mathrm{C}(2 \mathrm{~min})$ for 25 cycles. After the primary PCR, nested PCR was performed using sox9a and sox $9 b 5^{\prime}$ and $3^{\prime}$ GSP2 primers (Table 1), and nested universal primer with diluted primary PCR products. The nested PCR conditions were as follows: $94{ }^{\circ} \mathrm{C}(30 \mathrm{~s}), 65^{\circ} \mathrm{C}(30 \mathrm{~s})$, and $72{ }^{\circ} \mathrm{C}$ (2 min) for 35 cycles. All the nested PCR-amplified DNA fragments were gel purified, cloned in TOPO cloning vector (Invitrogen), sequenced, and analyzed using LaserGene software 3.05 (DNASTAR, Madison, WI, USA). The nucleotide and deduced amino acid sequences of sox $9 a$ and sox $9 b$ cDNAs were verified using the NCBI BLAST search.

\section{Tissue distribution by RT-PCR}

Tissue distribution pattern of sox9a and sox9b in adult catfish was carried out using RT-PCR. For this, total RNA was extracted from different tissues (brain, spleen, gill, heart, intestine, kidney, liver, testis, and ovary) of adult catfish using the Sigma TRI-reagent method. RT was carried out with $5 \mu \mathrm{g}$ of total RNA using oligo $\mathrm{d}(\mathrm{T})_{18}$ by superscript-III (Invitrogen) at $50{ }^{\circ} \mathrm{C}$ in a thermal cycler (Applied Biosystems, Foster City, CA, USA). PCR amplification was done at $94{ }^{\circ} \mathrm{C}(1 \mathrm{~min}), 58{ }^{\circ} \mathrm{C}$ $(30 \mathrm{~s})$, and $72{ }^{\circ} \mathrm{C}(1 \mathrm{~min})$ for 30 cycles using sox9aF-, sox9aR-, 
sox $9 b F$, and sox $9 b R$-specific primers (Table 1$)$. $\beta$-actin was PCR amplified at $94{ }^{\circ} \mathrm{C}(1 \mathrm{~min}), 60{ }^{\circ} \mathrm{C}(30 \mathrm{~s})$, and $72{ }^{\circ} \mathrm{C}(1 \mathrm{~min})$ for 30 cycles using $\beta$-actin-specific primers (Table 1 ) as an internal control to test the quality of cDNA template.

\section{Semi-quantitative RT-PCR}

Semi-quantitative RT-PCR as described elsewhere (Kwon et al. 2001) was carried out to study the expression patterns of sox9a and sox $9 b$ in adult and developing gonads. For this, total RNA was prepared from adult and developing gonads collected from juvenile catfish at different age groups (50, 75, 100, and $150 \mathrm{dph}$ ). RT was performed as mentioned above. PCR amplification was done using a thermal cycler (Applied Biosystems) under the following conditions: $94{ }^{\circ} \mathrm{C}(1 \mathrm{~min})$, $60{ }^{\circ} \mathrm{C}(30 \mathrm{~s})$, and $72{ }^{\circ} \mathrm{C}(1 \mathrm{~min})$ for 30 cycles using sox $9 a-$ and sox $9 b$-specific primers (Table 1 ). Catfish $\beta$-actin was PCR amplified at $94{ }^{\circ} \mathrm{C}(1 \mathrm{~min}), 60^{\circ} \mathrm{C}(30 \mathrm{~s})$, and $72{ }^{\circ} \mathrm{C}(1 \mathrm{~min})$ for 28 cycles using $\beta$-actin-specific primers (Table 1 ) as an internal control.

\section{Real-time quantitative RT-PCR}

Expression of sox9a and sox9b was analyzed by relative qRTPCR using SYBR Green detection method. Total RNA was extracted from the adult testis and ovary samples, which were collected during four different phases (preparatory, prespawning, spawning, and post-spawning phases) of reproductive cycle of catfish using the Sigma TRI-reagent method. RT was carried out with $1 \mu \mathrm{g}$ total RNA and random hexamer primers using superscript-III (Invitrogen) according to the manufacturer's protocol. Successful RT was confirmed for all samples by performing PCR amplification of $\beta$-actin. Real-time-specific primers for sox $9 a$, sox $9 b$, and $\beta$-actin (Table 1) were designed using Primer Express software (Applied Biosystems) such that at least one of the primers spanned the junction of two exons, giving a single cDNA PCR product and precluding amplification of genomic DNA. PCR was then carried out in $25 \mu \mathrm{l}$ reaction in triplicate using power SYBR Green PCR mastermix (Applied Biosystems) in a ABI-7500 fast real-time PCR machine (Applied Biosystems) at $95^{\circ} \mathrm{C}(15 \mathrm{~s})$ and $60{ }^{\circ} \mathrm{C}(1 \mathrm{~min})$ for 40 cycles according to the manufacturer's protocol. Dissociation curve analysis was performed for each sample to check single amplification. During PCR, fluorescence accumulation resulting from DNA amplification was recorded using the ABI Prism 7000 sequence detection system software (Applied Biosystems). Cycle threshold $\left(C_{\mathrm{t}}\right)$ values were obtained from the exponential phase of PCR amplification. We took $\beta$-actin as an endogenous control as it did not show any significant change in $C_{\mathrm{t}}$ values in different phases or treatments. The sox 9 expression was normalized against $\beta$-actin expression, generating a $\Delta C_{\mathrm{t}}$ value $\left(\Delta C_{\mathrm{t}}=\operatorname{sox} 9 C_{\mathrm{t}}-\beta\right.$-actin $\left.C_{\mathrm{t}}\right)$. Relative expression was then calculated according to the equation $2^{-\Delta C_{t}}$.

\section{In vitro culture of testicular slices in L-15 medium}

Testes from catfish in preparatory phase were dissected under sterile conditions and kept in ice-cold Leibovitz (L-15) culture medium (Sigma). Testicular slices of $20 \mu \mathrm{m}$ thickness were prepared using Mcllwain tissue chopper (vibratome). Testicular slices were individually transferred to tissue culture plates containing $2 \mathrm{ml}$ of L-15 medium supplemented with $10 \mathrm{mM}$ HEPES and antibiotics (penicillin, $100 \mathrm{IU} / \mathrm{ml}$; streptomycin, $0.1 \mathrm{mg} / \mathrm{ml}$ ). Testicular slices were cultured for $24 \mathrm{~h}$ at $20-22{ }^{\circ} \mathrm{C}$ in the presence $100 \mathrm{IU} / \mathrm{ml}$ of hCG or saline. At each time interval of $0,6,12$, and $24 \mathrm{~h}$, slices were collected from both hCG- and saline-treated samples, and washed with ice-cold phosphate buffer ( $\mathrm{pH}$ 7.4), and total RNA was prepared using Sigma TRI-reagent. The expression of sox9a was quantified for each time interval using qRT-PCR. Likewise, the effect of 11-KT (Wako Pure Chemical Industries Ltd, Osaka, Japan) on sox9a expression was also examined by treating the testicular slices with $100 \mathrm{ng} / \mathrm{ml}$ of $11-\mathrm{KT}$ at different time points. For this purpose, 11-KT was first dissolved in absolute ethanol and later reconstituted in the L-15 culture medium. The expression of sox9a was then analyzed using qRT-PCR.

\section{Western blot analysis}

Western blot analysis was carried out to detect Sox9 protein in catfish gonadal tissue homogenates using polyclonal Sox9 antibody (LifeSpan Biosciences, Seattle, WA, USA) raised against $\mathrm{N}$-terminal region (1-150 amino acids) of human Sox9 protein that showed 88.5 and $78 \%$ homology with the $\mathrm{N}$-terminal region of catfish Sox9a and Sox9b proteins respectively. Adult testis and ovary tissues were homogenized in $250 \mu \mathrm{l}$ of homogenization buffer containing $50 \mathrm{mM}$ Tris- $\mathrm{HCl}$ $(\mathrm{pH}$ 7.4), $150 \mathrm{mM} \mathrm{NaCl}, 1 \mathrm{mM}$ dithiothreitol, $0.1 \%$ Triton $\mathrm{X}-100$, and $0.1 \mathrm{mM}$ phenylmethylsulphonyl fluoride using a Sigma hand homogenizer. One hundred micrograms of each sample with a pre-stained marker were electrophoresed through a $15 \%$ SDS-polyacrylamide gel and transferred onto nitrocellulose membrane (Pall Life sciences, Port Washington, NY, USA). Membrane was blocked in 5\% skimmed milk powder in Tris-buffered saline (TBS) for $1 \mathrm{~h}$ at room temperature. After blocking, membrane was washed five times for 10 min each in TBS with $0.1 \%$ Tween 20 (TBST) solution, and incubated with 1:1000 dilution of polyclonal human Sox 9 antibody at $4{ }^{\circ} \mathrm{C}$ for overnight in $0.5 \%$ skim milk powder/TBST solution. Blot was washed and incubated with secondary antibody alkaline phosphatase-conjugated goat anti-rabbit IgG (Bangalore Genei, Bengaluru, India) for $1 \mathrm{~h}$. After washing, blot was developed using BCIP-NBT (Bangalore Genei).

\section{Immunohistochemistry}

Both adult and juvenile gonads were fixed in 4\% PFA, processed, and embedded in paraplast (Sigma). Sections were cut at $3 \mu \mathrm{m}$ thickness using a microtome (Leica, Wetzlar, Germany). Testis and ovary sections were deparaffinized in xylene, rehydrated in successively lower graded concentrations of ethanol, and then treated with $0.1 \% \mathrm{H}_{2} \mathrm{O}_{2}$ for $15 \mathrm{~min}$ to prevent endogenous peroxidase reaction. The sections were washed in $0.1 \mathrm{M}$ PBS and then blocked with $10 \%$ normal goat serum in PBS for $30 \mathrm{~min}$ at room temperature. Sections were then incubated overnight at $4{ }^{\circ} \mathrm{C}$ in 1:200 dilution of human SOX9 polyclonal antibody or anti-Sox9 pre-absorbed with excess of synthetic peptide for overnight. Later sections were 
washed in PBS with $0.1 \%$ Tween 20 (PBST) for 10 min and then incubated with 1:500 diluted biotinylated secondary antibody (Vector Laboratories, Burlingame, CA, USA) at room temperature for $1 \mathrm{~h}$. The sections were incubated with avidinbiotinylated HRP complex (ABC) reagent provided in VECTASTAIN Elite ABC kit (Vector Laboratories) for $30 \mathrm{~min}$ at room temperature. The sections were washed in PBS, and color was developed using commercially supplied 3,3'-diaminobenzidine as chromogen and $\mathrm{H}_{2} \mathrm{O}_{2}$ as substrate for HRP (Vector Laboratories). The sections were washed, dehydrated in graded ethanol, cleared in xylene, and mounted using DPX mountant. Photomicrographs were taken using Olympus CX41 bright field microscope (Olympus, Tokyo, Japan).

\section{Whole-mount IHC}

Whole-mount IHC was performed according to the procedure reported earlier (Wang et al. 2006) with a few modifications for the detection of Sox9 protein in the ovary of juvenile and mature catfish. Gonads were fixed overnight at $4{ }^{\circ} \mathrm{C}$ in $4 \%$ PFA, and dehydrated through a methanol series in PBS and kept in $-80{ }^{\circ} \mathrm{C}$ for a few days. Samples were rehydrated through a reverse methanol series, and blocked with PBS containing $3 \%$ skimmed milk powder and $0.1 \%$ Triton X-100 (PBMT) overnight at $4{ }^{\circ} \mathrm{C}$. Samples were then incubated overnight at $4{ }^{\circ} \mathrm{C}$ in PBMT containing $2 \%$ BSA and $1: 200$ dilution of polyclonal Sox 9 antibody, followed by 15 min washes in PBST $(0.1 \%$ Triton $\mathrm{X}-100 / \mathrm{PBS})$ for five times at $4{ }^{\circ} \mathrm{C}$. As a negative control, Sox 9 antibody pre-incubated with excess of Sox9 synthetic peptide overnight at $4{ }^{\circ} \mathrm{C}$ was used as primary antibody. Primary antibody was detected with 1:500 dilution of alkaline phosphatase-conjugated anti-rabbit secondary antibody (Vector Laboratories) in PBMT overnight at $4{ }^{\circ} \mathrm{C}$ followed by PBST washes. For enzyme detection, samples were incubated with BCIP-NBT in NTMT buffer $(0.1 \mathrm{M} \mathrm{NaCl}, 0.1 \mathrm{M}$ Tris- $\mathrm{HCl}, \mathrm{pH} 9.5,50 \mathrm{mM} \mathrm{MgCl}_{2}$, and $0.1 \%$ Tween 20) for 15-30 min. After optimal color development, the reaction was stopped by a PBST wash.

\section{Statistical analysis}

All the results were expressed as mean \pm s.E.M. Differences between groups were analyzed for statistical significance by one-way ANOVA followed by Student-Newman-Keuls post hoc test using SigmaPlot 9.0 software. A probability of $P<0.05$ is considered statistically significant.

\section{Declaration of interest}

The authors declare that there is no conflict of interest that could be perceived as prejudicing the impartiality of the research reported.

\section{Funding}

A Grant-in-Aid from University Grants Commission (UGC) (F. No. 34-412/2008), India, to B Senthilkumaran supported this work completely.

\section{Acknowledgements}

K Raghuveer acknowledges Council of Scientific and Industrial Research for his senior research fellowship. We thank our ViceChancellor, Prof. Seyed E Hasnain, and the Dean, Prof. M Ramanadham, for allowing us to use the Genomics and Microarray facility of School of Life Sciences (SLS), University of Hyderabad. We also thank the support from UGC Centre for Advanced Studies programme for the SLS.

\section{References}

Amores A, Force A, Yan YL, Wang YL, Fritz A, Amemiya C, Lynch M, Prince V, Ho R, Ekker M et al. 1998 Zebrafish hox clusters and vertebrate genome evolution. Science 282 1711-1714. (doi:10. 1126/science.282.5394.1711)

Barrionuevo F, Taketo MM, Scherer G \& Kispert A 2006 Sox9 is required for notochord maintenance in mice. Developmental Biology 295 128-140. (doi:10.1016/j.ydbio.2006.03.014)

Bi W, Deng JM, Zhang Z, Behringer RR \& de Crombrugghe B 1999 Sox 9 is required for cartilage formation. Nature Genetics 22 85-89. (doi:10.1038/8792)

Bishop CE, Whitworth DJ, Qin Y, Agoulnik AI, Agoulnik IU, Harrison WR, Behringer RR \& Overbeek PA 2000 A transgenic insertion upstream of Sox9 is associated with dominant XX sex reversal in the mouse. Nature Genetics 26 490-494. (doi:10.1038/ 82652)

Chen J \& Heckert LL 2001 Dmrt1 expression is regulated by folliclestimulating hormone and phorbol esters in postnatal Sertoli cells. Endocrinology 142 1167-1178. (doi:10.1210/en.142.3.1167)

Chiang EF, Pai CI, Wyatt M, Yan YL, Postlethwait J \& Chung B 2001 Two sox9 genes on duplicated zebrafish chromosomes, expression of similar transcription activators in distinct sites. Developmental Biology 231 149-163. (doi:10.1006/dbio.2000.0129)

Choudhary B, Ganesh S \& Raman R 2000 Evolutionary conservation of the gene Cvsox9 in the lizard, Calotes versicolor, and its expression during gonadal differentiation. Development Genes and Evolution 210 250-257. (doi:10.1007/s004270050311)

Cresko WA, Yan YL, Baltrus DA, Amores A, Singer A, RodriguezMari A \& Postlethwait JH 2003 Genome duplication, subfunction partitioning, and lineage divergence: Sox9 in stickleback and zebrafish. Developmental Dynamics 228 480-489. (doi:10.1002/ dvdy.10424)

Du QY, Wang FY, Hua HY \& Chang ZJ 2007 Cloning and study of adulttissue-specific expression of Sox9 in Cyprinus carpio. Journal of Genetics 86 85-91. (doi:10.1007/s12041-007-0013-z)

Foster JW, Dominguez-Steglich MA, Guioli S, Kwok C, Weller PA, Stevanovic M, Weissenbach J, Mansour S, Young ID, Goodfellow PN et al. 1994 Campomelic dysplasia and autosomal sex reversal caused by mutations in an $S R Y$-related gene. Nature 372 525-530. (doi:10.1038/372525a0)

Guo Y, Cheng H, Huang X, Gao S, Yu H \& Zhou R 2005 Gene structure, multiple alternative splicing, and expression in gonads of zebrafish Dmrt1. Biochemical and Biophysical Research Communications 330 950-957. (doi:10.1016/j.bbrc.2005.03.066)

Kent J, Wheatley SC, Andrews JE, Sinclair AH \& Koopman P 1996 A male-specific role for SOX9 in vertebrate sex determination. Development 122 2813-2822.

Klüver N, Kondo M, Herpin A, Mitani H \& Schartl M 2005 Divergent expression patterns of Sox 9 duplicates in teleosts indicate a lineage specific subfunctionalization. Development Genes and Evolution 215 297-305. (doi:10.1007/s00427-005-0477-x)

Kobayashi T, Kajiura-Kobayashi H, Guan G \& Nagahama Y 2008 Sexual dimorphic expression of DMRT1 and Sox9a during gonadal differentiation and hormone-induced sex reversal in the teleost fish Nile tilapia (Oreochromis niloticus). Developmental Dynamics 237 297-306. (doi:10.1002/dvdy.21409) 
Koopman P, Schepers G, Brenner S \& Venkatesh B 2004 Origin and diversity of the Sox transcription factor gene family genome-wide analysis in Fugu rubripes. Gene 328 177-186. (doi:10.1016/j.gene. 2003.12.008)

Kwon JY, McAndrew BJ \& Penman DJ 2001 Cloning of brain aromatase gene and expression of brain and ovarian aromatase genes during sexual differentiation in genetic male and female Nile tilapia Oreochromis niloticus. Molecular Reproduction and Development 59 359-370. (doi:10.1002/mrd.1042)

Lynch M \& Force A 2000 The probability of duplicate gene preservation by subfunctionalization. Genetics 154 459-473.

Morais da Silva S, Hacker A, Harley V, Goodfellow P, Swain A \& LovellBadge R 1996 Sox9 expression during gonadal development implies a conserved role for the gene in testis differentiation in mammals and birds. Nature Genetics 14 62-68. (doi:10.1038/ng0996-62)

Moreno-Mendoza N, Harley VR \& Merchant-Larios H 1999 Differential expression of SOX9 in gonads of the sea turtle Lepidochelys olivacea at male- or female-promoting temperatures. Journal of Experimental Zoology 284A 705-710. (doi:10.1002/(SICl)1097010X(19991101)284:6<705::AID-JEZ12 > 3.0.CO;2-1)

Nakamoto M, Suzuki A, Matsuda M, Nagahama Y \& Shibata N 2005 Testicular type Sox9 is not involved in sex determination but might be in the development of testicular structures in the medaka, Oryzias latipes. Biochemical and Biophysical Research Communications 333 729-736. (doi:10.1016/j.bbrc.2005.05.158)

Piera-Velazquez S, Hawkins DF, Whitecavage MK, Colter DC, Stokes DG \& Jimenez SA 2007 Regulation of the human SOX9 promoter by Sp1 and CREB. Experimental Cell Research 313 1069-1079. (doi:10.1016/j.yexcr.2007.01.001)

Postlethwait J, Amores A, Cresko W, Singer A \& Yan YL 2004 Subfunction partitioning, the teleost radiation and the annotation of the human genome. Trends in Genetics 20 481-490. (doi:10.1016/j. tig.2004.08.001)

Qin Y \& Bishop CE 2005 Sox9 is sufficient for functional testis development producing fertile male mice in the absence of Sry. Human Molecular Genetics 14 221-1229. (doi:10.1093/hmg/ ddi133)

Raghuveer K \& Senthilkumaran B 2009 Identification of multiple dmrt1s in catfish: localization, dimorphic expression pattern, changes during testicular cycle and after methyltestosterone treatment. Journal of Molecular Endocrinology 42 437-448. (doi:10.1677/JME-09-0011)

Sassone-Corsi P 1995 Transcription factors responsive to cAMP. Annual Review of Cell and Developmental Biology 11 355-377. (doi:10. 1146/annurev.cb.11.110195.002035)

Sekido R \& Lovell-Badge R 2008 Sex determination involves synergistic action of SRY and SF1 on a specific Sox9 enhancer. Nature $\mathbf{4 5 3}$ 930-934. (doi:10.1038/nature06944)

Sekido R, Bar I, Narvaez V, Penny G \& Lovell-Badge R 2004 SOX9 is up regulated by the transient expression of $S R Y$ specifically in Sertoli cell precursors. Developmental Biology 274 271-279. (doi:10.1016/ j.ydbio.2004.07.011)

Shin HS, An KW, Park MS, Jeong MH \& Choi CY 2009 Quantitative mRNA expression of sox 3 and DMRT1 during sex reversal, and expression profiles after GnRHa administration in black porgy, Acanthopagrus schlegeli. Comparative Biochemistry and Physiology 154 150-156. (doi:10.1016/j.cbpb.2009.05.013)

Sinclair AH, Berta P, Palmer MS, Hawkins JR, Griffiths BL, Smith MJ, Foster JW, Frischauf AM, Lovell-Badge R \& Goodfellow PN 1990 A gene from the human sex-determining region encodes a protein with homology to a conserved DNA-binding motif. Nature 346 240-244. (doi:10.1038/346240a0)

Skinner MK 1991 Cell-cell interactions in the testis. Endocrine Reviews 12 45-77. (doi:10.1210/edrv-12-1-45)

Spotila LD, Spotila JR \& Hall SE 1998 Sequence and expression analysis of WT1 and Sox9 in the red-eared slider turtle, Trachemys scripta. Journal of Experimental Zoology 281 417-427. (doi:10.1002/ (SICI)1097-010X(19980801)281:5 < 417::AID-JEZ7 > 3.0.CO;2-R)
Swapna I, Rajasekhar M, Supriya A, Raghuveer K, Sreenivasulu G, Rasheeda MK, Majumdar KC, Kagawa H, Tanaka H, Dutta-Gupta A et al. 2006 Thiourea-induced thyroid hormone depletion impairs testicular recrudescence in the air-breathing catfish, Clarias gariepinus. Comparative Biochemistry and Physiology 144 1-10. (doi:10.1016/j.cbpa.2006.01.017)

Takamatsu N, Kanda H, Ito M, Yamashita A, Yamashita S \& Shiba T 1997 Rainbow trout SOX9, cDNA cloning, gene structure and expression. Gene 202 167-170. (doi:10.1016/S0378-1119(97) 00483-6)

Takase M, Noguchi S \& Nakamura M 2000 Two Sox 9 messenger RNA isoforms, isolation of cDNAs and their expression during gonadal development in the frog Rana rugosa. FEBS Letters 466 249-254. (doi:10.1016/S0014-5793(00)01078-4)

Thomsen MK, Butler CM, Shen MM \& Swain A 2008 Sox9 is required for prostate development. Developmental Biology 316 302-311. (doi:10.1016/j.ydbio.2008.01.030)

Verhoeven G, Willems A, Denolet E, Swinnen JV \& De Gendt K 2010 Androgens and spermatogenesis: lessons from transgenic mouse models. Philosophical Transactions of the Royal Society of London. Series B: Biological Sciences 365 1537-1556. (doi:10.1098/rstb. 2009.0117)

Vidal VP, Chaboissier MC \& De Rooij DG 2001 Sox9 induces testis development in XX transgenic mice. Nature Genetics 28 216-217. (doi:10.1038/90046)

Wade MG \& Van der Kraak G 1991 The control of testicular androgen production in the goldfish: effects of activators of different intracellular signalling pathways. General and Comparative Endocrinology 83 337-344. (doi:10.1016/0016-6480(91)90138-V)

Wagner T, Wirth J, Meyer J, Zabel B, Held M, Zimmer J, Pasantes J, Bricarelli FD, Keutel J, Hustert E et al. 1994 Autosomal sex reversal and campomelic dysplasia are caused by mutations in and around the SRY-related gene SOX9. Cell 79 1111-1120. (doi:10.1016/00928674(94)90041-8)

Wang Y, Ristevski S \& Harley VR 2006 SOX13 exhibits a distinct spatial and temporal expression pattern during chondrogenesis, neurogenesis, and limb development. Journal of Histochemistry and Cytochemistry 54 1327-1333. (doi:10.1369/jhc.6A6923.2006)

Western PS, Harry JL, Graves JAM \& Sinclair AH 1999 Temperature dependent sex determination, upregulation of Sox9 expression after commitment to male development. Developmental Dynamics 214 171-177. (doi:10.1002/(SICl)1097-0177(199903)214:3<171:: AID-AJA1 > 3.0.CO;2-S

Xia W, Zhou L, Yao B, Li CJ \& Gui JF 2007 Differential and spermatogenic cell-specific expression of DMRT1 during sex reversal in protogynous hermaphroditic groupers. Molecular and Cellular Endocrinology 263 156-172. (doi:10.1016/j.mce. 2006.09.014)

Yan YL, Miller CT, Nissen RM, Singer A, Liu D, Kirn A, Draper B, Willoughby J, Morcos PA, Amsterdam A et al. 2002 A zebrafish Sox9 gene required for cartilage morphogenesis. Development 129 5065-5079.

Yokoi H, Kobayashi T, Tanaka M, Nagahama Y, Wakamatsu Y, Takeda H, Araki K, Morohashi K \& Ozato K 2002 Sox9 in a Teleost Fish, Medaka (Oryzias latipes): evidence for diversified function of Sox 9 in gonad differentiation. Molecular Reproduction and Development 63 5-16. (doi:10.1002/mrd.10169)

Zhou R, Liu L, Guo Y, Yu H, Cheng H, Huang X, Tiersch TR \& Berta P 2003 Similar gene structure of two Sox $9 a$ genes and their expression patterns during gonadal differentiation in a teleost fish, rice field eel (Monopterus albus). Molecular Reproduction and Development 66 211-217. (doi:10.1002/mrd.10271)

Received 27 April 2010

First decision 1 June 2010

Accepted 28 June 2010 